\title{
Noble estates and their owners in the Orłów county in the second half of the $18^{\text {th }}$ century
}

Summary. The Orłów county, being one of the smallest in the Polish-Lithuanian Commonwealth, was a part of the Łęczyca voivodship. The towns, villages and other real estate in this county belonged exclusively to the nobility and to the Catholic Church. The contemporary historians investigating the ownership of these properties in the $16^{\text {th }}$ and $17^{\text {th }}$ centuries unambiguously determined that the accumulation of properties and creation of large estates made up of a dozen or more villages did not occur in the said county. The owners of noble estates were not too wealthy, neither in the country nor in the voivodship. The situation did not change in the next century, as confirmed by the study into the records of the chimney tax in 1775 and the head tax in 1790, which covered the entire Łęczyca voivodship. At the time, the most affluent was the voivode of Łęczyca, Szymon Dzierzbicki, being in possession of the town of Bielawa and eight villages, as well as the voivode of Vitebsk, Józef Sołłohub, the owner of Żychlin, six full villages and a part. In 1790, the largest property, including six villages, belonged to the general of the Russian army, Jan Sołłohub. It confirms that no noble estate that would be composed of over ten towns existed in the Orłów county. The area was dominated by small estates, consisting of one or two villages, or their parts, which mainly belonged to the less affluent nobility. In some cases, a village was owned by two or three noblemen, but sometimes even by thirteen. Over the next 15 years, the situation has not changed significantly since the process of property consolidation did not take place. The group of landowners did not grow smaller, and the analysis of the number of chimneys in the villages of the Orłow county in 1790 indicated that a considerable part of the Orłow nobility was working the land and was also tax exempt for having small estate.

Keywords: Polish nobility in the $18^{\text {th }}$ century, Orłów county, noble estate.

\footnotetext{
*E-mail: m.kobierecki@vp.pl.
} 
$\mathrm{N}$ umerous studies were carried out on the Orłów county, located in the old-Polish Łęczyca voivodship. The biggest contribution was made by Stanislaw Marian Zajaczkowski, who was interested in settlement, ownership structure or church territorial divisions in the area during the Middle Ages ${ }^{1}$. In his indepth studies, Zajaczkowski takes into account various factors, such as boundaries, geographical location and natural environment, considering types of soils, hydrographic data and the level of forestation. The results of the analysis brought him to a conclusion that, in the said period, the conditions in the Orłow area were favorable for the development of agriculture. Another factor boosting the economic development of the region was the road network, which existed at the end of the Middle Ages and the beginning of the modern era, and which facilitated communication ${ }^{2}$.

The administrative division of the Łeczyca voivodship originated in the Middle Ages and remained unchanged in the modern era. The voivodship was split into three counties, out of which the one of Orłow was the smallest, covering $629.8 \mathrm{~km}^{2}$, while the counties of Łęczyca and Brzeziny measured $2447.59 \mathrm{~km}^{2}$ and $1300.85 \mathrm{~km}^{2}$, respectively ${ }^{3}$. Another county, of Inowłódz, figures in the resolutions of the diet of 1726 . However, it did not function in reality as the records of the municipal books are missing, and the records of the Brzeziny county dating back to the $18^{\text {th }}$ century contain no information on the subject. Perhaps it was associated with the

${ }^{1}$ S.M. Zajaczkowski, Powiat orlowski do lat siedemdziesiatych XVI wieku. Studia $z$ dziejów osadnictwa struktury własnościowej $i$ stosunków kościelnych, Łódź 1996; i d e m, Uwagi o przeszłości Orłowa do lat siedemdziesiątych XVI wieku, "Rocznik Łódzki" 1996, vol. XLIII, pp. 53-72; ide m, Sieć parafialna na obszarze przedrozbiorowego powiatu orłowskiego do końca XVI wieku, Kutno 2001.

${ }^{2}$ I d e m, Powiat orłowski..., pp. 14-33.

3 Stanisław M. Zajączkowski quotes the data on the size of the county after Tadeusz Sobczak and Leszek Kajzer, who based on Adolf Pawiński's work. Yet, according to S.M. Zajaczkowski, the total area of the county was $4376.8 \mathrm{~km}^{2}$, while T. Sobczak reports that it amounted to $4378.2 \mathrm{~km}^{2}$. The difference stems from the use of different, more or less detailed data. The total area rounded to two decimals was $4378.24 \mathrm{~km}^{2}$. Another figure is given in Atlas historyczny..., $4326 \mathrm{~km}^{2}$. S.M. Zajączkowski, Powiat orłowski..., p. 7; L. Kajzer, Studia nad świeckim budownictwem obronnym województwa łęczyckiego w XIII-XVII wieku, "Acta Universitatis Lodziensis", Folia Archaeologica 1980, vol. I, p. 10; T. S o b c zak, Zmiany $w$ stanie posiadania dóbr ziemskich $w$ województwie łęczyckim od XVI do XVIII wieku, "Roczniki Dziejów Społecznych i Gospodarczych" 1955, vol. XVII, p. 166; Atlas historyczny Polski, vol. V (Województwo sieradzkie i województwo tęczyckie w drugiej połowie XVI wieku), part 2, ed. H. Rutkowski, Warszawa 1998, p. 49. 
creation of the hierarchy of the land office in Inowłodz at the time. Nevertheless, the term "Inowłódz county" appears in the review of royal estate carried out in 1765 and in the mandate of 1782 issued by the Łęczyca sejmik. Finally, during the sitting of the Great Diet, the Inowłódź county was recognized as a separate administrative unit; yet, no boundaries were established. Thus, the Brzeziny county hadn't been altered until the second partition of Poland.

In the $18^{\text {th }}$ century, there was no royal property in the Orłów county. It resulted from the actions of monarchs in the previous centuries, who were giving away royal properties to the clergy, as in the case of the complex of Zduny estate, or to the noblemen who received Żychlin and Doliwów. Also, the majority of the estates in the county were owned by the middle and petty nobility. The value of estates was increasing during that time, mainly due to the formation of new settlements. Nonetheless, the estates were frequently undergoing divisions as an outcome of, for example, inheritance ${ }^{4}$. The estates comprised of numerous villages as well as single villages were being split into parts. By contrast, entering into marriages and acquisition lead to increases in estates and revenues. In many cases, it was conditioned by the skills and abilities of an individual. The phenomena were particularly noticeable since the Orłow county was small and the accumulation of several villages by the same owner led to the social advancement and a leap in the hierarchy of the local nobility. After the owner died, however, the large estate was frequently divided ${ }^{5}$.

The aforementioned conclusions were drawn by Zajaczkowski, who distinguishes seven complexes of properties in the Orłów county which, in the $15^{\text {th }}$ and $16^{\text {th }}$ century, belonged to the wealthy nobility. Although it is known that they did not survive in the long run and a part of the villages came into other hands, it might be difficult to determine when exactly those changes occurred since in the municipal books the landowners still appeared as the proprietors of multiple villages, while they actually owned only a share of their previous estates. Zajaczkowski also claims that the largest portion of settlements was in the hands of the petty nobility. The differences in the distribution of wealth were not significant and the owners of one or two villages could be classified as middle

4 S.M. Zajaczkowski, Powiat orłowski.., p. 146.

5 Ibidem, p. 147. 
nobility, which seems to be typical in the assessment of a very small area ${ }^{6}$.

In this respect, the situation did not change in the $16^{\text {th }}$ century, as confirmed by the study based on the analysis of the treasury-oriented sources from the second half of the said century, carried out by Tadeusz Sobczak. According to Sobczak, the Orłów nobility was mostly in possession of estates which consisted of a small number of villages. He calculated that in the entire Łęczyca voivodship, $60 \%$ of the villages were split into parts and the majority was located in the Orłow county. It should be emphasized that those split villages were not equal in size and their parts could constitute various properties and have different landowners ${ }^{7}$. And yet, only $35 \%$ of the noblemen's villages in the county formed single-village estates $^{8}$. Solely $20 \%$ of the villages, generally remaining as a whole, created multi-village estates, while some of them were also made of the properties situated outside the Orłów county. Furthermore, some estates did not include any village as a whole but just some parts of various villages. At times, their area, counted in łans, was much larger than of those comprised of one or two, or even three villages ${ }^{9}$.

On the basis of the collected information on the noble estates in the Orłow county, Sobczak distinguishes three groups of nobility. In the first and the third group, he makes additional divisions. The poorest group is the partial nobility with 134 estates, which were comprised of 54 and a half villages. The second group owned 37 estates, out of which seven were multi-village ones and the remaining had just one village. In total, they consisted of 40 and a half villages. Twenty-four multi-village estates belonged to the last group ${ }^{10}$. In order to complete and confirm the picture of noblemen's wealth, it should be pointed out that the highest percentage of the neighborhood nobility in the Łęczyca voivodship was inhabiting the Orłów county. In addition, there were noble estates smaller than those of kmiecie; for instance, in 25 villages there were 286

${ }^{6}$ As stated by S.M. Zajaczkowski, the records from tax collections in, for instance, $16^{\text {th }}$ century published by Adolf Pawiński constituted a more accurate source of information on estate owners. Ibidem, p. 161, 162, 218.

7 T. Sobczak, op. cit., p. 168, 169.

8 Ibidem, p. 172.

9 Ibidem, p. 173.

${ }^{10}$ In the third group, the biggest of four estates had twelve villages and the rest, six, three and two. Ibidem, p. 171. 
farm properties of nobility, 46 in the size of one łan. Such nobility lived north of the Bzura River and, in quite substantial numbers, on the border between the Łęczyca and Orłów counties ${ }^{11}$.

Even though the ownership structure did not shift markedly in the following century, the increase of multi-village estates was observed in the Leczyca voivodship in the second half of the $17^{\text {th }}$ century. In 1661, these properties belonged to the Szczawinski (approx. 20 villages) families, the Korycinski (11.5 villages) families or to Adam Bełdowski, Mateusz Rysinsski and the diseased Rajmund Bykowski (all of which consisted of nine villages). But owing to the visible regression in the settlements, a large number of landowners (1185 people, as estimated) lost their estates and joined the group of people without properties who could look for source of income in the cities, e.g. in Piotrków, where regular tribunal sessions were held $^{12}$. In the years 1661-1683, no changes were observed in the Orłów county either. According to the division into four groups, which was put forward by Wojciech Szczygielski in order to determine the wealth of the nobility in the Łeccyca voivodship, it can be assumed that the most of villages belonged to the middle nobility. In the case of the Orłow county, $45.1 \%$ of the villages were owned by the group in 1661, whereas in 1683, 55.7\%. Over these 22 years, changes in the ownership occurred also in other groups. After the "deluge", the second group owning the largest number of villages was the wealthy nobility $(28.3 \%)$, followed by the petty nobility $(26.6 \%)$. For comparison: in $1683,33.3 \%$ of the villages were owned by the poorest noblemen, and $11 \%$ by the wealthy nobility. Neither of the two groups included representative of the magnates, the most affluent nobility. An estimation on the number of estates complements the village ownership proportions. In 1661 as well as in 1683, the majority of the estates (almost $75 \%$ ) were in the hands of the poorest nobility, which clearly indicates radical impoverishment of noble-born inhabitants of this county. The group of the wealthy nobility owned six estates and later only two. As stated by Szczygielski, this change took place due to several reasons: enlargement of folwarks, debt of properties, desertification of settlements

11 Ibidem, p. 174, 175.

${ }^{12}$ W. Szczygielski, Struktura społeczno-własnościowa szlachty łęczyckiej w poczatkach drugiej połowy XVII w., "Acta Universitatis Lodziensis", "Zeszyty Naukowe Uniwersytetu Łódzkiego", Nauki Humanistyczno-Społeczne, Folia Historica, Series I, "Feudalizm", 1979, issue 57, p. 161, 162, 163. 
and deterioration of living conditions, which was caused not only by the damages from the 1655-1660 war with Sweden. The accumulation of properties was also visible among the middle nobility, with an increase from $22.7 \%$ to $25.4 \%$. It was possible thanks to a relatively large number of farming nobles and the resulting consolidation of different properties ${ }^{13}$.

The tariff of the 1775 chimney tax and of the 1790 head tax constitute a meaningful source of information on the wealth of the nobility from the Orłow county in the $18^{\text {th }}$ century. The former was first introduced during the sitting of the general sejm in 1629, which was motivated by the search of funds for the war with Sweden. At the beginning, it was calculated according to the roofs, not the chimneys, and the rates in the cities and villages varied. The tax fulfilled its main function in the $17^{\text {th }}$ century; yet, charging wealthier and poorer taxpayers the same amount was not fair. In the next century, the tax was withdrawn ${ }^{14}$. In the $17^{\text {th }}$ century, the other tax, the head tax, was often imposed on the Jewish population, and sometimes on the representatives of other nations, such as the Scots, Persians, Armenians and Greeks, who were merchants. For the first time, the head tax was accepted in 1590 but it was not collected. In the second half of the $17^{\text {th }}$ century, however, the tax law was reintroduced and it was exercised, at the beginning occasionally, and gradually more frequently. Since 1717, apart from the revenue from hiberna, the tax for the lodging and feeding the troops, the head tax became the main source of army funds. Its rate varied depending on the taxpayer's place in the social structure and the office he held. With the passage of time, the tax rate was being increased and heavier burden was falling on the poorer social groups ${ }^{15}$.

It wasn't until the modifications in tax law during Stanisław August's reign that the situation has changed. The delegation sejm established a new chimney tax on February 14, 1775, and it was

13 Ibidem, p. 155, 159, 160.

${ }_{14}$ M. Nycz, Geneza reform skarbowych sejmu niemego. Studium z dziejów skarbowo-wojskowych $z$ lat 1697-1717, Poznań 1938, p. 51, 53; A. Filipczak-Kocur, Skarbowość Rzeczypospolitej 1587-1648. Projekty, ustawy, realizacja, Warszawa 2006, pp. 53-58.

15 M. Nycz, op. cit., pp. 53-54; M. Drozdowski, Podstawy finansowe działalności państwowej w Polsce 1764-1793. Działalność budżetowa Sejmu Rzeczypospolitej w czasach panowania Stanisława Augusta Poniatowskiego, WarszawaPoznań 1975, p. 34; A. Filipczak-Kocur, op. cit., pp. 65-66. 
to replace the head, the hiberna and the old chimney taxes. This general chimney tax applied to all royal, church and private properties, with the rates set at seven and five zlotys from a smoke, i.e. a chimney in a village, and it was paid each year, which appears more just than the head tax at the same rate for everyone. The tax revenue became the main source of the state budget, providing the crown with five million zlotys ${ }^{16}$. The Great Diet introduced another change, imposing the $10 \mathrm{gr}$ tax on the income from a noble estate. Also, the head tax tariff was determined for the Łęczyca voivodship in 1790 .

Both tax systems ${ }^{17}$ did not differ from each other as the basic information given was the number of chimneys, along with a name of the town or village and of the owner(s). However, in the 1775 tariff, the total number of chimneys in a given town or village was mentioned, indicating how many of those belonged to the nobility, the clergy or the peasant landowners. The tax systems were drawn for the whole voivodship, which was split into counties, and counties into parishes where an alphabetical list of described towns and villages was placed.

The tariffs make it possible to determine the number of towns and villages in the Orłow county. According to the data quoted by Sobczak, there were 159 villages and five towns belonging to the nobility and to the Church ${ }^{18}$. The cities of Bielawa, Oporów, Orłow, Sobota and Żychlin are also named in Atlas historyczny Polski, in addition to 172 villages, $90 \%$ of which belonged to the nobility ${ }^{19}$.

16 Volumina legum, vol. VIII, p. 88; T. Korzon, Wewnętrzne dzieje Polski za Stanisława Augusta (1764-1794), vol. III, Kraków-Warszawa 1897, pp. 158-159, p. 160; M. Drozdowski, op. cit., p. 74,78 .

17 The information on both tax tariffs survived until today and is stored in the Central Archives of Historical Records in Warsaw. The 1775 chimney tariff is to be found in the Łęczyca municipal books, varia No. 7 "Taryfa podymnego i czopowego 1775 r.", while the 1790 head tariff is in the same records, varia No. 11 "Taryfy podatku podymnego $z$ dóbr dziedzicznych, duchownych i królewskich województwa łęczyckiego". T. Wierzbowski, Akty ziemskie i grodzkie XIV-XVIII w. województw wielkopolskich, [in:] Monumenta iuris, vol. VI, Warszawa 1917, p. 121; H. Wajs, Materiały skarbowe $w$ aktach ziemskich i grodzkich $w$ AGAD (na przykładzie akt sieradzkich i łęczyckich), "Miscellanea Historico-Archivistica" 1999, vol. X, pp. 76-115.

18 T. Sobczak, op. cit., p. 178, 179.

19 In the entire Łęczyca voivodship, $82.5 \%$ of the villages belonged to the nobility. Noblemen also owned almost $65 \%$ of the voivodship area. Atlas historyczny Polski, vol. V, Tab. 8, p. 63, 71. 
Such serious variations in the data referring to village numbers should be attributed to the method employed by the researchers, e.g. considering part of them as a separate settlement units. In the second half of the $17^{\text {th }}$ century, around 1661,137 villages belonged to the nobility, whereas the 1683 tax records report $126^{20}$. In the $18^{\text {th }}$ century, the 1775 tariff distinguishes 165 settlements, including three towns (Bielawy, Sobota and Żychlin), whereas Oporow and Orłów were recognized as villages. In terms of ownership, 15 of the villages belonged to the Church and 147 belonged to the nobility. In this group, 17 villages were deserted and only seven were associated with particular owners and in one case, two noblemen owned a deserted village ${ }^{21}$. Four of the landowners had other properties, while Stanisław Kożuchowski, with the deserted Ostoja ${ }^{22}$, and the Łęczyca master of the hunt, Feliks Zawisza, with Zakrzewo ${ }^{23}$, both in the Sobota parish ${ }^{24}$, did not own any other village in the county. A separate example was a deserted settlement of Przykuty ${ }^{25}$, belonging to the family of Przedpełski. It was marked as uninhabited but with the chimney tax ascribed to it.

In the 1790 tariff of the head tax, 162 settlements were listed, less than 15 years before, which resulted from the omission of the 13 deserted settlements that were considered previously. Yet, the number of church properties increased up to 16 because Baków Dolny got to be included in the list. One hundred forty-three villages and the towns of Bielawa, Sobota and Żychlin belonged to the nobility. What is more, new towns appeared, such as Marcinów

20 W. Szczygielski, op. cit., p. 155, 158.

${ }^{21}$ It refers to Łazino Zdzarowskie (now Łazinek), a deserted settlement of Franciszek Wawelski and Wojszycki of the unknown first name, which I omit in the calculations of estates and owners as the two men had other properties as well. Atlas historyczny Polski, vol. V, p. 119.

${ }^{22}$ According to Atlas historyczny... in $16^{\text {th }}$ century the deserted Ostoja (now Emilianów) was situated in the Bakowo parish. While in the 1775 chimney tariff records ascribe it to the parish of Sobota. Probably it was the same village, located on the border between the two parishes. Ibidem, p. 123.

${ }^{23}$ This article provides contemporary names of settlements. Only if a settlement did not survive until today, its name is kept in the original form. All the names were verified with Atlas historyczny Polski, vol. V.

${ }^{24}$ The tariff records mention different Stanislaw Kożuchowski, the cupbearer of Orłów, owning three villages. However, it cannot be confirmed that it was the same person for the lack of reference. A similar situation occurred in the case of Feliks Zawisza, as an existing Feliks Zawisza, the Łęczyca master of the hunt, can be referred to as well.

${ }^{25}$ Atlas historyczny... does not provide a contemporary name. 
in the Strzegocin parish, founded as a Hollander settlement, or Wola Prosperowa in the Oporow parish. The deserted settlements from 1775 were also included, e.g. Dobiesławice ${ }^{26}$ and Lisie Jamy ${ }^{27}$ from the Łęki Kościelne parish, or Górki ${ }^{28}$ from the Ciechosłanice parish. They were listed as chimneys or they were meant to be paid for with the tax of $10 \mathrm{gr}$.

The information obtained from the tariff records allowed to assess the size of estates, the financial status of the nobility, the condition of the settlement network or the size of the settlements. As for the last estimate, it was established that in 1775, the villages with the biggest number of chimneys were: Łęki Kościelne (47 chimneys, owned by the Leźnicki), Oporów (42; Józef Sołłohub, the voivode of Vitebsk), Orłow (32; Jan Brochocki, the standard-bearer of Łęczyca), Dobrzelin (27; Jan Bartoszewski, the pantler of Gostynin) and Skrzeszewy (Mikorski, the cupbearer of Gostynin). Over the course of 15 years, the order of the three biggest villages did not change: Łęki Kościelne (39 chimneys, owned by Tomasz Guzowski), Oporów (36; Jan Sołłohub, general of the Russian army) and Orłów (32; Antoni Brochocki, royal chamberlain). What followed was Śleszyn Wielki (29; Bagniewski, the pantler of Bratslav) and Dobrzelin (Edmund Bratoszewski, the standard-bearer of Gostynin). Compared to the 1775 records, those villages, as well as other settlements, experienced the drop in the number of chimneys.

Another issue was the size of the noble estates in the Orłow county. They are known to have consisted of particular villages or their parts. Both sources of treasury records do not mention whether a given owner had properties in other counties. Therefore, the terms "wealth" or "estate" used in this work refer solely to properties of one owner that were located within the territory of the Orłow county. As presented in the above findings, there were no properties of the magnates, and it also applies to the second half of the $18^{\text {th }}$ century. In 1775 , the owner of the largest estate was the voivode of Łęczyca, Szymon Dzierzbicki. His estate was comprised of the city of Bielawa and villages: Bielawska Wieś, Brzozów, Leżajna, Mroga, Orenice, Oreniczki, Piaski and Piekary, in total, nine settlements with 175 chimneys. It should be emphasized that they constituted the whole estate of the voivode that was situated

\footnotetext{
${ }^{26}$ Today it does not exist. Atlas historyczny Polski, vol. V, p. 111.

27 Today it does not exist. Ibidem, p. 119.

${ }^{28}$ Currently, it is a part of the village Górki Pęcławskie. Ibidem, p. 113.
} 
only in the Orłów county. Another estate, which was in the hands of the voivode Sołłohub, consisted of the town of Żychlin and villages: Budzyń, Dobrzewy, Oporów, Oporówek, Wola Owsiana, Pasieki and a part of Jastrzęb, seven settlements and a part, with 186 chimneys. In this case, the voivode also held properties outside the Łęczyca voivodship ${ }^{29}$. The third on the list was the estate of Antoni Kossowski, the owner of five villages: Kręcieszki, Madeje ${ }^{30}$, Szewce Owsiane, Tarnow and Wojszyce; all of them were in the same parish and had 51 chimneys. Next, the four-village estates belonged to: Jan Krosnowski (Kaszewy Dworne, Kaszewy Kościelne, Kaszewy Tarnowskie, Konary), 39 chimneys; Adam Lasocki, the castellan of Sochaczew (Drogusza, Gosławice, Wola Gosławska, Oszkowice), 68; Antoni Podkański (Ciechosławice, Orątki, Pęcławice, Rogaszyn), 41; Feliks Stępowski (Golędzkie - deserted, Jaworzyna, Odolin, Odolinek), 16; Ignacy Wilkszycki (Płoszczonów ${ }^{31}$, Psary, Skubik, Waliszew), 56.

The breakdown of data looks different when the number of chimneys becomes the main criterion. The biggest number of chimneys in the estate had the voivode of Vitebsk, and next, the voivode of Łeczyca. As for the owners of four and five villages, the highest figure was reached by A. Lasocki, and the lowest by F. Stępowski, who stands out in the group. Some landowners held estates with 50 chimneys in each of their three or two villages, e.g.: Błociszewski (Konarzew, Witów and a part of Jasionna), 53; W. Zawisza, the master of the hunt of Łęczyca (town of Sobota and Sobocka Wieś), 51; Stanisław Bagniewski (Sołek, Śleszyn Wielki, Śleszynek ${ }^{32}$ and a part of Grzybów ${ }^{33}$ ), 50; J. Brochocki, the standard-bearer of Łęczyca (Mosiębrza, Orłów and a part of Stradzewo), 49. Moreover, Leźnicki

${ }^{29}$ See P.P. Romaniuk, Sołłohub (Ursyn Dowojna Sołłohub) Józef Antoni h. Prawdzic (1709-1781), kasztelan żmudzki i witebski, wojewoda witebski, [in:] Polski słownik biograficzny, vol. XL, Warszawa-Kraków 2000-2001, pp. 319-323; id e m, Sołłohub (Ursyn Dowojna Sołłohub) Jan Michał h. Prawdzic (1747-1812?), starosta sannicki, generał $w$ służbie rosyjskiej, [in:] ibidem, pp. 315-318; H. Żerek-Kleszcz, Majętność oporowska i Sołłohubowie w XVIII wieku, [in:] Oporów. Stan badań. Materiały $z$ sesji naukowej zorganizowanej $z$ okazji 50 rocznicy Muzeum w Oporowie 22 listopada 1999 roku, Oporów 2000, pp. 135-148.

${ }^{30}$ Currently, it is a part of the village Wojszyce. Atlas historyczny Polski, vol. V, p. 120 .

${ }^{31}$ Today the place does not exist. Ibidem, p. 124.

32 Today the place does not exist. Ibidem, p. 130.

${ }^{33}$ Atlas historyczny... does not mention Grzybów, the settlement in the Żychlin parish, as stated in both records of head tax tariffs. It names the village Grzybo- 
of the unknown first name, who owned only the village of Łęki Kościelne, held in possession 47 chimneys.

In 1790, most of the villages were owned by General J. Sołłohub: Dobrzewy, Jastrzębia, Kurów, Świechów, Oporów and Oporówek, which were comprised of 95 chimneys. He was followed by the voivode of Dzierzbick, owning five villages with life tenure (Borówek, Leżajna, Piaski, Piekary, Seligi) and two villages partially (Orenice and Oryniczki), 85 chimneys in total, and Antoni Kossowski with five villages (Kręcieszki, Madeje, Szewce Owsiane, Tarnów, Wojszyce) and one partially (Szewce Nadolne), having only 39 chimneys. The owners of five-village estates were the general of the crown army Tadeusz Błociszewski (Boczki Domaradzkie, Boczki Zarzeczne, Chlebowice, Konarzew, Witów, 31 chimneys) and the son of castellan of Rogoźno, Józef Molski (Ciechosławice, Orątki, Pęcławice, Rogaszyn and deserted Górka that also paid the tax, 48 chimneys). Among the proprietors of four villages were found Marianna Wilkszycka, the wife of the cupbearer of Orłow and the royal chamberlain A. Brochocki. They both owned one part of other villages, as well ${ }^{34}$. Neither of them had in possession more chimneys than those who owned five villages, even counting the villages of partial ownership. The owners of four-village estates include: the pantler of Inowłódź, Jan Krosnowski, the royal chamberlain Karol Skarbek and the castellan of Ovruch, Melchior Trzeciak ${ }^{35}$. Skarbek's estate was comprised of 88 chimneys, which is more than in the estate of Dzierzbicka. It was thanks to owning the town of Bielawa, having 67 chimneys at the time, including the one of the parish church. A similar situation can be observed in the case of the castellan of Gdańsk, Tomasz Pruszak, the owner of three villages and 82 chimneys. He owned the city of Żychlin which had 68 chimneys (out of which 54 formed a part of the castellan's

wo which was located in the parish of Śleszyno-Sołek and is now called Grzybów Hornowski. Ibidem, p. 113.

${ }_{34}$ Thanks to life tenure, Marianna Wilkszycka possessed Płoszczonów, Psary, Skubiki, Waliszew and a part of Mięsośnia. In total, she owned 58 chimneys. The royal chamberlain, A. Brochocki, owned Mirosławice, Mosiębrza, Orłów, Tomczyce and parts of Garbów, with the total of 72 chimneys. Ibidem, p. 112, 121, 131.

35 Jan Krosnowski owned villages Konary and Krzyżanów, the Hollander settlement Marcinów and deserted Lisie Jamy with one chimney, 36 chimneys in total. The city Bielawa, Bielawska Wieś, Brzozów and Mroga belonged to K. Skarbek, while M. Trzeciak owned Biała, Kruki, Szczyt and Zarębów, in total, 29 chimneys. Ibidem, p. 106, 113, 116, 118, 134, 136. 
estate $^{36}$ ), associated with higher revenue and considerable prestige. Apart from that, there were five proprietors of three or three and a part of village, two out of which, Bagniewski, the pantler of Bratslav and Cyprian Nakwaski, the starost of Wyszogród, owned 60 chimneys each. Eleven owners had two villages and part(s), among others Wincenty Bardziński who had in possession Sobota with 38 chimneys and his whole estate counted ten more ${ }^{37}$. It was the largest number of chimneys and exceeded the properties of Pawel Mikorski, the judge of the land court of Łęczyca and the owner of two villages and two parts ${ }^{38}$. This group was also formed by Antoni Grabski, the owner of nine chimneys, as well as Bartłomiej Przysiecki, 12. The rest possessed between 19 and 30 chimneys. Thirty owners had only one village, two out of whom had additionally a part. Tomasz Guzowski, the owner of the biggest village Łęki Kościelne, possessed the largest number of chimneys in the group, 36 . Besides, this group included the colonel of the crown army Antoni Głebocki, the owner of Plecka Dabrowa and the widow Trzcińska, who had Popówek. Both estates consisted of 23 chimneys each ${ }^{39}$. There were also eight owners of one village with three to six chimneys ${ }^{40}$.

In 1775, 142 owners and possessors were listed as holders of multi-village estates as well as estates consisting of villages owned partially in the Orłów county. Six women and eight marriages were to be found among them, plus four instances where inheritors were listed. The second tariff also details 142 landowners. On top of that, the Piarists of Łowicz who were proprietors of four settlements and the Pauline Fathers from Oporow owning one village should be added. In addition to the owners and five possessors

${ }^{36}$ Tomasz Tadeusz Pruszak owned Budzyń, Pasieka and Żychlin. In this city, there were 31 chimneys of Catholic townsmen, 23 Jewish ones and 14 belonging to the parish.

${ }^{37}$ In Sobota, only one chimney belonged to the parish, while 26 were in the hands of the Catholic townsmen, and 11, Jewish people.

${ }^{38}$ Paweł Mikorski's estate consisted of 42 chimneys.

39 Apart from that, one chimney in Plecka Dabrowa belong to the parish.

40 Three chimneys were to be found in each of the villages of Goliszew, Buszkówek and Ziewaniczki which belonged to Wojciech Kaliński, Andrzej Stęmpowski and the possessor Julianna Ziemięcka. Michał Elzanowski owned the Rybie village with four chimneys. Five chimneys were in: Drzewoszki Małe, Galice (today doesn't exist) and Buszków, whose owners were: Dęmbowski, Wincenty Domaradzki and the land bailiff of Łęczyca, Jan Rakowiecki. The Guminy Łętki village with six chimneys was in possession of the Skarżynski family, the settlement is not listed in Atlas historyczny... Ibidem, vol. V, p. 108, 111, 112, 127, 137. 
(two of whom were tenants), two men with life tenure were registered. In nine cases, the tenants of the village were women, including two with life tenure. Additionally, there were two inheritors and three marriages.

The presented information on the size of noble estates in the Orłow county in the second half of the $18^{\text {th }}$ century allow to assess their revenue and worth more accurately. The "village" criterion adopted in the assessment of estate size and used in literature on the subject as a universal factor in the comparison of noble estates has been readjusted to reflect situation more accurately. The villages are clearly not equal, as given in the records of both tariffs. Obtaining the data on the number of chimneys facilitated the completion of the picture which had been created basing only on the number of villages, especially that a single village could be split between several owners. When it comes to the Orłów county, the analysis of 1775 tariff clearly indicates that one-part estates were dominant in the area, and it applies to 83 of the cases. Other three estates were composed of two parts. One of the single-village estates that belonged to Franciszek Swiętosławski included additionally two parts, whereas five other estates had only one part in addition. Two out of two-village estates are known to possess also a part of another village: the one of Błociszewski (unknown by first name) and of J. Brochocki, the standard-bearer of Łęczyca. Only Stanisław Bagniewski owned a three-village estate and an additional part. Fifteen years later, 85 estates included one or two parts of a village, which accounts for $59.86 \%$ of all.

Based on the calculations in Table 1, more than $80 \%$ of the estates consisted of parts of villages or of an individual village. The remaining constituted between approx. $17 \%$ in 1775 to approx. $19 \%$ in 1790 . The results presented in the table allowed to refer to the studies that had been put forward by Sobczak and Szczygielski. The former researcher distinguishes three groups of owners: partial, single-village and multi-village ${ }^{41}$. Undoubtedly, such a division adequately reflects the situation of the nobility in the Łeczyca voivodship, as well as in the Orłow county. But as far as the second half of the $18^{\text {th }}$ century is concerned, the differences between the first two groups were quite subtle, and the major-

${ }^{41}$ Tadeusz Sobczak assumes that the owners of one or two incomplete villages fall into the one-village group. The multi-village owners are those who had more than two villages. T. Sobczak, op. cit., p. 168. 
ity of owners fell into these categories. According to the criteria adopted by the second author, based on the data from 1775 and $1790,60 \%$ of landowners constituted the petty nobility. The middle nobility held about $36 \%$ of estates, and the wealthy nobility $2-3 \%$. The magnates are not reported in the Orłow county. Furthermore, taking into consideration Szczygielski's study results which referred to 1661 and 1683 , it can be observed that the estates belonging to the petty nobility decreased by almost $15 \mathrm{pp}$, whereas the estates of the middle nobility increased by about the same percent. As for the wealthy nobility, no major change has been noted. The growth of more than $1 \mathrm{pp}$ over one hundred years is not enough to assume the property consolidation. Such a process was surely taking place, yet in the case of the middle nobility.

The number of villages in the noble estates in the Orłow county in the second half of the $18^{\text {th }}$ century

\begin{tabular}{|c|c|c|c|c|c|}
\hline No. & $\begin{array}{c}\text { No. of villages } \\
\text { in the estate }\end{array}$ & $\begin{array}{c}\text { No. of estates } \\
\text { in } 1775\end{array}$ & $\%$ & $\begin{array}{c}\text { No. of estates } \\
\text { in } 1790\end{array}$ & $\%$ \\
\hline 1 & one - two parts & 86 & 61,43 & 85 & 59,86 \\
\hline 2 & $1-1+$ parts & 30 & 21,43 & 30 & 21,13 \\
\hline 3 & $2-2+$ parts & 11 & 7,86 & 11 & 7,75 \\
\hline 4 & $3-3+$ parts & 5 & 3,57 & 6 & 4,22 \\
\hline 5 & $4-4+$ parts & 5 & 3,57 & 5 & 3,52 \\
\hline 6 & 5 or more & 3 & 2,14 & 5 & 3,52 \\
\hline Total & & 140 & 100 & 142 & 100 \\
\hline
\end{tabular}

S ource: author's own research.

These findings were confirmed by the analysis of the number of chimneys. In 1775, 39 estates were listed to have one chimney. In reality, they belonged to the nobility who worked the land themselves. According to the divisions adopted in the tariff records, five of them had chimney tax for peasants $(3.57 \%$ of the properties), 
and the remaining 34 , for manors $(24.29 \%)$. It is hard to determine whether many of the said nobles owned any properties outside the Orłów county. It may be assumed that most of them did not. Moreover, two nobles had had one part of two different with one chimney in each (Kamiński and Świecki, unknown by first names), and six others owned a part of a village with two chimneys. Some villages, however, happened to have two chimneys, like Leżajna (in the Oszkowice parish) or Żbiwiec (in the Bedlno parish). The former belonged to the voivode of Łęczyca, S. Dzierzbicki, and the latter to the standard-bearer of Inowłódz, Jan Stokowski.

In 1790, 50 estates made up of one chimney existed in the county, which accounted for more than $1 / 3$, i.e. $35.21 \%$ of the total. Forty-one out of those, i.e. $28.87 \%$ of all estates, were exempted from tax as they lacked sufficient income. The tax exemption also applied to the estate consisting of two single-chimney parts, and two other single-chimney estates did not have to pay the tax for one of their two parts ${ }^{42}$. The other three of the 13 two-chimney estates that were made of two parts were also tax-exempt. Some were partial but have in possession between three to six chimneys ${ }^{43}$. Summing up, out of 85 partial estates with one to five chimneys, 55\% did not pay tax, which was more than in the whole of the Łęczyca voivodship, i.e. $48.6 \%{ }^{44}$.

Table 2

The number of chimneys in noble estates in the second half of the $18^{\text {th }}$ century

\begin{tabular}{|c|c|c|c|c|c|}
\hline \multirow{2}{*}{ No. } & \multirow{2}{*}{ Chimneys } & \multicolumn{2}{|c|}{1775} & \multicolumn{2}{c|}{1790} \\
\cline { 3 - 6 } & & Estates & $\%$ & Estates & $\%$ \\
\hline 1 & 1 & 39 & 27,86 & 50 & 35,21 \\
\hline 2 & 2 & 20 & 14,28 & 14 & 9,86 \\
\hline 3 & 3 & 8 & 5,71 & 8 & 5,63 \\
\hline 4 & 4 & 6 & 4,29 & 5 & 3,52 \\
\hline
\end{tabular}

${ }^{42}$ In total, there were seven estates consisting of two one-chimney parts.

${ }^{43}$ Four estates had three chimneys. Two estates were made up of four chimneys. Four estates had five chimneys and the other four estates, six.

${ }_{44}$ T. Sobczak, op. cit., p. 181. 
Table 2 cd.

\begin{tabular}{|c|c|c|c|c|c|}
\hline \multirow{2}{*}{ No. } & \multirow{2}{*}{ Chimneys } & \multicolumn{2}{|c|}{1775} & \multicolumn{2}{c|}{1790} \\
\cline { 3 - 6 } & & Estates & $\%$ & Estates & $\%$ \\
\hline 5 & 5 & 2 & 1,43 & 8 & 5,63 \\
\hline 6 & $\begin{array}{c}\text { from } 6 \\
\text { to 10 }\end{array}$ & 26 & 18,57 & 12 & 8,46 \\
\hline 7 & $\begin{array}{c}\text { from 11 } \\
\text { to 20 } \\
\text { from 21 } \\
\text { to 30 }\end{array}$ & 16 & 11,43 & 17 & 11,97 \\
\hline 9 & $\begin{array}{c}\text { from 31 } \\
\text { to 50 }\end{array}$ & 9 & 5,71 & 12 & 8,46 \\
\hline 10 & $\begin{array}{c}\text { more than } \\
50\end{array}$ & 6 & 4,29 & 8 & 5,63 \\
\hline Total & & 140 & 100 & 142 & 100 \\
\hline
\end{tabular}

Source: author's own research.

The nobles who had their estates in the Orłów county belonged to the group of not too affluent landowners. It is not known to what extent it was influencing the divisions and mergers of villages; yet, these processes were taking place. In 1775, there were 30 split villages, which equals $20.41 \%$ of all, and in 1790 , there were 24 , which amounts to $16.78 \%$. The results are best illustrated in Table 3. An evident decrease was associated with the merger in 14 villages. This process could involve combining all parts together, as in nine out of 14 cases, but also merging two or three parts while the rest remained separate. On the other hand, the consolidation took place within a relatively short period of time, i.e. 15 years. Yet, for example, Wincenty Domaradzki succeeded in overtaking parts of the village Galice with five chimneys from four different owners. Most frequently two parts of villages were merged. Only Tomasz Magnuski, who owned one part of Młogoszyn, took over the other two parts from his relatives. Given such a short period of time, the consolidation process was not too impressive and in eight villages it did not occur at all. A negative phenomenon of further divisions could be observed in 11 villages. In 1775 , Grzybów was leading in the number of owners, nine, whereas Groszki had eight and Szewce Nagórne, seven. Fifteen years later, the order was changed: Groszki had 13 owners, Grzybów, 11, Szewce 
Nagórne i Kamienna, nine. Within a brief period, the last of the mentioned settlements was divided from four into nine parts. Only in one case the records of both tariffs give the same name. Perhaps after the death of remaining owners, their heirs were appearing. This was undoubtedly what happened in Groszki, where the property divisions among the representatives of the Groszkowski and the Iskrzycki families added to the number of the village owners. In the remaining nine instances, two new parts were separated, and in the other three instances, one new part.

Table 3

The number of parts in the noblemen's villages in the Orłów county in the second half of the $18^{\text {th }}$ century

\begin{tabular}{|c|c|c|c|c|}
\hline $\begin{array}{c}\text { Parts } \\
\text { of a village }\end{array}$ & $\begin{array}{c}\text { No. of villa- } \\
\text { ges in } 1775\end{array}$ & $\begin{array}{c}\text { \% of villages } \\
\text { in } 1775\end{array}$ & $\begin{array}{c}\text { No. of villa- } \\
\text { ges in } 1790\end{array}$ & $\begin{array}{c}\% \text { of villages } \\
\text { in } 1790\end{array}$ \\
\hline 2 & 13 & 8,84 & 8 & 5,59 \\
\hline 3 & 6 & 4,08 & 7 & 4,89 \\
\hline 4 & 5 & 3,40 & 2 & 1,40 \\
\hline 5 & 2 & 1,36 & 0 & 1,40 \\
\hline 6 & 1 & 0,68 & 1 & 0,70 \\
\hline 7 & 1 & 0,68 & 0 & - \\
\hline 8 & 1 & 0,68 & 1 & 0,70 \\
\hline 9 & 0 & 0,68 & 1 & 0,70 \\
\hline 10 & 0 & - & 1 & 0,70 \\
\hline 11 & 0 & - & 24 & 0,70 \\
\hline 13 & 30 & -40 & 16,78 \\
\hline Total & 1 & - & & \\
\hline
\end{tabular}

S ource: author's own research.

The analysis of the 1775 and 1790 tariffs shows that the noble estates in the Orłow county belonged to the noblemen who were not too affluent and some of them worked the land. The short period 
of time, i.e. 15 years, does not allow to observe any process which would change the situation for the owners of the noble estates in the Orłow county in the second half of the $18^{\text {th }}$ century. The initial state, i.e. the number of towns and villages from the two tax records, excluding the deserted settlements, seems to be unchanged. Nevertheless, when it comes to the number of chimneys in noble estates, the situation looks different. It can be observed that the number of chimneys in the largest villages fell in the said period. For this reason, an owner of the bigger number of chimneys could possess less villages than the one who owned more settlements, which confirms imperfections of adopting a number of villages as a universal criterion. Basing on these tariff records exposes certain shortcomings since they were produced to collect taxes and their creators were not preoccupied with accuracy. It is difficult to assess to what degree the included information departs from the truth. But sure$1 y$, what was occurring independently of the above-mentioned were the divisions of estates and the decrease in the group of the most affluent nobility in the Orłow county. These processes cannot be observed by simply taking into consideration the number of villages in each estate, but by analyzing the number of chimneys. The fortunes of the largest estate of the voivode of Łęczyca, S. Dzierzbicki, can serve as a perfect example. In 1790, his widow had in possession only half of the chimneys that her husband owned 15 years before. Table 2 depicts the phenomenon, as in 1775 there were 26 properties with six to ten chimneys each, while in 1790 only 12 such estates remained. Most likely a portion of them was merged with bigger estates, which is reflected in the data on the bigger number of chimneys. However, the most apparent increase is recorded in the lowest group, including parts of villages that must have come from bigger estates. In addition, there was a slight increase in the estates with five chimneys. Another occurrence was the accumulation of parts of settlements in the hands of one owner. The span of time is not long enough to determine how long this trend continued. The process did not increase the number of villages that were owned by one person. The acquisition of one, two or more parts was already successful enough as it allowed to merge them into one village in the future. Yet, the merger was never certain to happen, while the possibility of further divisions after the owner's death was always present. 


\section{Bibliography}

\section{Handwriting SOURCes}

The Central Archives of Historical Records in Warsaw (Archiwum Główne Akt Dawnych) [AGAD]

The Łęczyca municipal books, varia No. 7, 11 .

(Księgi grodzkie łęczyckie)

\section{Printed sources}

Volumina legum, vol. VIII, Petersburg 1860.

\section{STUdies}

Atlas historyczny Polski, vol. V (Województwo sieradzkie i województwo łęczyckie w drugiej połowie XVI wieku), part 2, ed. H. Rutkowski, Warszawa 1998.

Drozdowski M., Podstawy finansowe działalności państwowej w Polsce 1764 1793. Działalność budżetowa Sejmu Rzeczypospolitej w czasach panowania Stanisława Augusta Poniatowskiego, Warszawa-Poznań 1975.

Filipczak-Kocur A., Skarbowość Rzeczypospolitej 1587-1648. Projekty, ustawy, realizacja, Warszawa 2006.

Kajzer L., Studia nad świeckim budownictwem obronnym województwa łęczyckiego w XIII-XVII wieku, "Acta Universitatis Lodziensis", Folia Archaeologica 1980, vol. I, 1980, pp. 3-414.

Korzon T., Wewnętrzne dzieje Polski za Stanisława Augusta (1764-1794), vol. III, Kraków-Warszawa 1897.

Nycz M., Geneza reform skarbowych sejmu niemego. Studium z dziejów skarbowowojskowych z lat 1697-1717, Poznań 1938.

Romaniuk P.P., Sołłohub (Ursyn Dowojna Sołłohub) Józef Antoni h. Prawdzic (1709-1781), kasztelan żmudzki i witebski, wojewoda witebski, [in:] Polski słownik biograficzny, vol. XL, Warszawa-Kraków 2000-2001, pp. 319-323.

Romaniuk P.P., Sołłohub (Ursyn Dowojna Sołłohub) Jan Michał h. Prawdzic (1747-1812?), starosta sannicki, generał w służbie rosyjskiej, [in:] Polski słownik biograficzny, vol. XL, Warszawa-Kraków 2000-2001, pp. 315-318.

Sobczak T., Zmiany $w$ stanie posiadania dóbr ziemskich $w$ województwie łęczyckim od XVI do XVIII wieku, "Roczniki Dziejów Społecznych i Gospodarczych" 1955, vol. XVII, pp. 163-193.

Szczygielski W., Struktura społeczno-własnościowa szlachty łęczyckiej $w$ począkach drugiej połowy XVII w., "Acta Universitatis Lodziensis", "Zeszyty Naukowe Uniwersytetu Łódzkiego”, Nauki Humanistyczno-Społeczne, Folia Historica, Seria I, "Feudalizm", 1979, issue 57, pp. 151-166.

Wajs H., Materiały skarbowe w aktach ziemskich i grodzkich w AGAD (na przykładzie akt sieradzkich i łęczyckich), "Miscellanea Historico-Archivistica" 1999, vol. X, pp. 76-115. 
Wierzbowski T., Akty ziemskie i grodzkie XIV-XVIII w. województw wielkopolskich, [in:] Monumenta iuris, vol. VI, Warszawa 1917, pp. 4-178.

Zajaczkowski S.M., Powiat orłowski do lat siedemdziesiatych XVI wieku. Studia $z$ dziejów osadnictwa struktury własnościowej i stosunków kościelnych, Łódź 1996.

Zajączkowski S.M., Sieć parafialna na obszarze przedrozbiorowego powiatu orłowskiego do końca XVI wieku, Kutno 2001.

Zajaczkowski S.M., Uwagi o przeszłości Orłowa do lat siedemdziesiątych XVI wieku, "Rocznik Łódzki" 1996, vol. XLIII, pp. 53-72.

Żerek-Kleszcz H., Majętność oporowska i Sołłohubowie w XVIII wieku, [in:] Oporów. Stan badań. Materiały $z$ sesji naukowej zorganizowanej z okazji 50 rocznicy Muzeum w Oporowie 22 listopada 1999 roku, Oporów 2000, pp. 135-148.

Michat Kobierecki

\section{Dobra szlacheckie i ich właściciele w powiecie orłowskim w drugiej polowie XVIII wieku}

Powir owiat orłowski, należący do najmniejszych pod względem powierzchni w Rzeczypospolitej Obojga Narodów, wchodził w skład województwa łęczyckiego. Miasta, wsie i inne nieruchomości istniejące w tym powiecie należały jedynie do szlachty i Kościoła katolickiego. Współcześni historycy badający własność owych dóbr w XVI i XVII stuleciu ustalili jednoznacznie, że na obszarze owego powiatu nie doszło do kumulacji i utworzenia kilkunastowioskowych bądź jeszcze większych majątków. $Z$ drugiej strony właściciele dóbr szlacheckich nie byli zbyt zamożnymi w kraju, jak również w województwie. Sytuacja nie zmieniła się w następnym stuleciu, co potwierdzają wyniki badań rejestrami podymnego z $1775 \mathrm{r}$. i pogłównego z 1790 r., które objęły całe województwo łęczyckie. W tym czasie do najbogatszych należeli wojewoda łęczycki Szymon Dzierzbicki, posiadający miasto Bielawę i osiem wsi, czy wojewoda witebski Józef Sołłohub, właściciel miasta Żychlina oraz sześciu i części wsi. W 1790 r. największy majątek, liczący sześć wsi, należał do generała wojsk rosyjskich Jana Sołłohuba. To potwierdza, że na obszarze powiatu orłowskiego nie było majatków szlacheckich składajacych się $z$ więcej niż 10 miejscowości. Dominowały majątki niewielkie, składające się z jednej, dwu bądź części wsi, należących w większości do ubogiej szlachty. W niektórych przypadkach wsie miały po dwóch-trzech właścicieli, a zdarzały się przypadki, że nawet 13 . W ciagu 15 lat nie nastapiła zdecydowana zmiana, ponieważ nie dokonał się proces scalania dóbr. Ta grupa właścicieli nie zmniejszyła się, a analiza liczby dymów we wsiach powiatu orłowskiego z $1790 \mathrm{r}$. wykazała, że spora część orłowskiej szlachty zajmowała się praca na roli i była również zwolniona $z$ płacenia podatków ze względu na zbyt mały majątek.

Słowa kluczowe: polska szlachta w XVIII w., powiat orłowski, własność szlachecka. 